\title{
Evaluating the Effectiveness of Public Procurement Performance Management Systems in Local Governments
}

\author{
Andrea Stefano Patrucco, Davide Luzzini \& Stefano Ronchi \\ Local Government Studies \\ Volume 42, Issue 5, 2 September 2016, Pages 739-761
}

\begin{abstract}
Increasing the effectiveness, efficiency and compliance of public procurement (PP) has become an ongoing concern for governments. Public administrations at different levels are realising that - in order for PP to fulfil its mission - appropriate control and diagnostic systems must be put in place. This study aims to investigate the architecture of PP performance measurement systems (PP-PMSs) in local governments, drawing on four case studies from Italy and four from Wales. The theoretical background is provided by the emerging literature on procurement PMSs in the private context as well as the specific literature on the public sector. PP-PMSs are specifically analysed with respect to performance areas covered (i.e. cost, quality, time, compliance, innovation, sustainability). Results show that performance dimensions should be extended beyond traditional cost measures, with KPIs not limited to those imposed by national/regional regulation. Furthermore, we show that this is likely to happen where the procurement function is recognized as strategic in the public institution.
\end{abstract}

Keywords: Local Government; Public procurement; Performance; Regulation 


\section{Introduction}

Performance management has become a key element in modern public sector governance, as many developed and developing countries have the need to measure organizational and individual efficiency in order to ensure that public sector organizations fulfil their mission (Rhodes et al., 2012).

Furthermore, performance management is critical for a government function public procurement (PP) - that has increasingly grown complex, controlling a relevant share of public expenditures (up to 70\%; e.g., in Greece) and national GDP (up to 25\%; e.g., in the Netherlands; OECD, 2013), and continuing to evolve both conceptually and organisationally (Thai, 2008). Nowadays, the possibility for public administrations to fulfil their mission greatly depends upon the rationalization of such a relevant share of expenditures, and the potential contribution to the organizational performance provided by the procurement function greatly depends upon the way such function is managed and controlled, making PP performance management systems (PP-PMSs) particularly relevant.

Policy makers, academics, and practitioners alike recognize that PP has evolved from a clerical signoff-ridden set of activities to a strategic function that enhances efficiency in public organizations, regulates markets, and promotes sustainable development (Thai, 2008). In particular, the PP system aims at delivering efficiency and "value for money" in the use of public funds, whilst adhering to EU requirements and to national laws and policies (Erridge and McIlroy, 2002). Performance management is about seeking to answer the fundamental question of whether the procurement system is ultimately delivering according to its objectives and, in case of performance gaps, which 
kind of corrective actions should be put in place.

Unfortunately, policy debates often focus on how to include new objectives rather than assessing the feasibility and compatibility of existing ones (Kwon and Jang, 2011). Furthermore, measuring the effectiveness of procurement choices for each single objective is still an issue. Overall, PP-PMSs should constitute a reliable diagnostic tool assessing the functioning of PP at different governmental levels and showing a potential course of improvement (Verbeeten, 2008).

With these premises, the paper has two main objectives. After a brief overview of past academic contributions, we propose a theoretical framework for PP-PMSs, clarifying performance areas and measures to be included, their level of analysis, and the link with general PP goals. Then, in the second part, we explore the implementation of the proposed model by using cross-case analysis in local governments from Wales and Italy, in order to assure theoretical replication and include situations with different maturity levels. Finally, we conclude drawing some suggestions for practitioners, and proposing an agenda for future research.

\section{Literature review}

We review the literature about PMSs in the public sector, in order to collect general insights for the purpose of this study. Next, we focus on extant literature about PP-PMSs, to summarize state-of-the-art and open challenges.

\subsection{Theoretical background: performance management in public institutions}

Performance measurement, as the process of quantifying the efficiency and effectiveness 
of actions (Neely, 2005), has attracted increasing interest since the late 1980s (Saiz et al., 2007). While performance management is relevant for both the private and public sector and several common issues can be found, scholars have emphasized some notable differences in the behaviour of public and private sector organizations (e.g. Wall and Martin, 2003).

Historically, public sector organizations have heavily relied on action controls, i.e. rules and procedures (Boland and Fowler, 2000; Radnor and McGuire, 2004). In the last decades, the discipline of New Public Management (NPM) has depicted the features of public sector reforms, promoting a change in management control of public sector organizations and shifting towards output controls (Lapsley, 1999; Higgins, 2005; Turley et al., 2015). Many Western countries have promoted initiatives to stimulate the use of performance management practices in public sector organizations (including central government, local governments, and other public sector organizations; e.g. Angiola and Bianchi, 2013; Charbonneau and Van Ryzin, 2013). However, when NPM reforms translate into practices, usually a gap arises between intended actions and actual results, and it becomes necessary to understand which factors influence the effective implementation of PMSs (Poister and Streib, 1999). Grounding on path dependency theory (e.g. Mahoney, 2000), the public sector management literature highlights that organizations that continuously and voluntarily search for improvement are more likely to apply mature models and methodologies in an effective manner (McAdam and Walker, 2003), creating a path towards a constant improvement of management techniques (including PMSs). Verbeeten (2008) supports this view, describing PMSs as a way to direct the organizational path of public bodies towards performance improvement, 
helping employees to understand what the organization wants, and politicians and public managers to make the taxpayers aware of how their money is used.

\subsection{Performance management for PP}

When designing an integrated PMS for public institutions, all potential areas contributing to value creation for citizens should be included (e.g. Boyne, 2006). PP being a pivotal function for public institutions (Murray, 2001, PP-PMSs should be designed for reporting and improving procurement in government departments, thus fostering the achievement of the overall public objectives.

In the private context, scholars have long been directing their attention to the need to measure procurement efficiency and effectiveness (Gushée and Boffey, 1928; Colton, 1962). With the increasing importance of procurement departments within firms, scholars have developed more sophisticated models, mostly focusing on the type of measures to be adopted, such as efficiency/cost, total cost of ownership, on-time deliveries, accuracy, quality, innovation, sustainability, internal customer satisfaction, and professionalism

(Chao et al., 1993; Beamon, 1999; Gunasekaran et al., 2001; Easton et al., 2002; Axelsson et al., 2002; Lardenoije et al., 2005; Caniato et al., 2014). However, recent studies acknowledge that the design and implementation of procurement PMSs has been under-investigated and that we should know more about how these systems work (Caniato, et al., 2014; Luzzini et al., 2014). The lack of insights is even more evident in the context of PP.

Indeed, contributions on PP-PMSs can be grouped at three levels. Only few studies propose a broader approach on PP-PMSs design: Knudsen (1999) identifies the key elements that should be investigated in the system, such as productivity of resources, 
process material and information flows, and satisfaction of final users; Kumar et al. (2005) develop a PMS for healthcare procurement including measures for activities in the procurement department, quality of suppliers, internal customers satisfaction and composition of the supply base; finally, OECD (2011) suggests three different (but interdependent) levels of performance should be included, (i) performance of the national PP system; (ii) performance of the contracting authorities’ operations; (iii) performance of an individual contract. As efficiency seeking has been recognized as the most important objective for PP so far (e.g. McAfee and McMillan, 1989), a second group of works focus the attention on specific measures to evaluate procurement performance in this area, especially in terms of budget savings (e.g. Bennedsen and Schultz, 2011; Costantino et al., 2012; Bergman and Lundberg, 2013) and process and organizational efficiency (e.g. Croom and Brandon-Jones, 2007; Coulson, 2008; Raisbeck et al., 2010; Karjalainen, 2011; Doherty et al., 2013). Finally, some studies broaden the scope of PPPMSs, by supporting the need to measure PP functioning also in other areas beyond cost and efficiency, such as quality of purchases (e.g. Nisar, 2007; Yuan et al., 2009), process execution (e.g. Rendon, 2008), sustainability (e.g. Preuss, 2009; Walker and Brammer, 2012; Amann et al., 2014) and innovation (e.g. Aschhoff and Sofka, 2009).

\section{Research objectives}

From the literature review, we can first infer that: PP-PMSs are a fundamental tool to ensure the efficient and effective management of PP processes; PP performance is a crucial driver of the capability of public organizations to fulfil their objectives; general literature about procurement PMSs partially adapts to the case of PP. From this evidence, 
we worked in two directions. On the one hand, we designed a research framework clarifying the main performance areas that should be considered as far as PP is concerned, and connecting such areas to PP processes and - ultimately - to the overall objectives of public organizations. On the other hand, we developed three research questions aimed at exploring how PP-PMSs are managed in order to support the role of the PP function.

\subsection{Research framework}

In designing the general structure of the PP-PMS, we grounded on extant literature to identify three key components. Firstly, since the aim of measuring is to assess whether operations function in accordance with the objectives (Hayes and Wheelwright, 1984), we started considering the typical PP goals: regulatory (i.e. compliance with the European Union PP Directives), commercial (i.e. use of market mechanisms to reduce cost and increase quality), and socio-economic (i.e. support to the wider government policy) (Erridge, 2005).

Secondly, considering contributions specifically focused on the design of the private procurement PMS (e.g. Caniato et al., 2014) we isolated some characteristics that are relevant to PP as well: namely, the main performance areas, as well as their level of analysis. In line with these contributions as well as the suggestions of international nongovernmental organizations (including OECD, 2013; NIGP, 2012), we were able to identify six relevant performance areas for PP that should be measured at both the internal processes and supply contract level, in order to assess the achievements of PP specific goals (Figure 1 and Table 1). This research framework might be applied to a single public organization, to a specific part of the public sector (e.g. the procurement 
system in the health sector), a region, and/or even the whole national procurement system.

-FIGURE 1-

-TABLE 1-

\subsection{Research questions}

The framework has been designed to answer three main research questions.

A frequent critique to traditional PMSs is that they are too financially oriented (Lardenoije et al., 2005. This limitation is particularly relevant when dealing with PP activities: traditionally seen as an administrative and clerical function (Matthews, 2005), governments usually utilize purely cost-oriented measures to assess PP functioning (Afonso et al., 2005; Quirck, 2005). The most common KPI is about saving as a result of the competitive bidding process (Bergman and Lundberg, 2013). This is especially true when the procurement department does not hold considerable decision-making authority, but mainly acts as a service provider for other departments, and adheres to strict policies and guidelines (Verdeaux, 2003). However, due to the sheer magnitude of PP at all government levels, and its importance for both the (local) economy and value creation for citizens, it seems restrictive to evaluate its impact through cost and saving metrics; consequently, we wonder how the PP-PMS can be designed to include performance areas other than cost. Therefore, we formulate the following research question:

RQ1: Beyond cost metrics, what is the appropriate set of performance areas and measures for PP? 
In connection to the above research question, the procurement literature suggests that the maturity of the procurement function in planning its strategy, monitoring processes, and implementing improvement programmes drives the procurement status within the organization (Murray, 2001). We conceive the procurement status as the extent to which procurement can act as a value-adding function, as a consequence of several factors, including: recognition from other departments, the position in the organization hierarchy, and the involvement in strategic planning (Thai and Piga, 2007). Even in the public context, several scholars recognize the strategic value-adding potential of PP (e.g. Telgen et al., 2007; Thai and Piga, 2007) and the need to assess its performance (Raymond, 2008). As a consequence, we expect that the level of maturity of the PP-PMS would foster a greater status of the procurement department and therefore enable a greater value creation potential. Indeed, introducing compelling measures and metrics for procurement processes would be one of the basic ways to assess the role of the procurement department and support its evolutionary path to a higher status. The question is how the PP-PMS can be designed in order to catalyse the PP status. To this end, we formulate the following research question:

RQ2: In order to support the role of PP in public institutions, how can the PP-PMS be designed?

Finally, dealing with public institutions, we must consider the role played by regulation. Recent reforms influence the structure of PMSs at different governmental 
levels (McAdam et al., 2011). In some countries, every year the central government publishes a set of indicators that must be monitored and reported by public institutions, distinguished for departmental areas (this happens e.g. in the UK, Italy, Germany and the Netherlands), including also guidelines about number and type of indicators to be measured and reported. These mandatory requirements may also affect the procurement area, as direct and/or indirect procurement measures are likely included. However, despite regulatory requirements enabling transparency and monitoring, they may lead public institutions to a misalignment between performance measures imposed by the regulation and the actual mission of public bodies. For example, McLean et al. (2007) suggest that general performance measures imposed by the government are often too general, thus missing the real picture of the PP system functioning. Thus, we are interested to understand how different regulatory contexts might influence the design of the PP-PMS and, for this reason, we formulate the third research question as follows:

\section{RQ3: How does the regulation affect the design of the PP-PMS?}

\section{Research methodology}

In order to test the proposed framework and the research hypothesis, a case-based research method was selected, more suitable for qualitative understanding (Meredith 1998). Case studies provide new and creative insights, develop new theories and have high validity with practitioners (Voss et al., 2002), especially when questions of why, what, and how are asked (Yin, 1999). 


\subsection{Case selection}

First, a decision in terms of public institutions to be included in the research was made. Considering the unit of analysis used by some previous works (e.g. Murray, 2001; Bartlett and Dibben, 2002; McAdam et al., 2011), we decided to focus our attention on local authorities, as they seemed a convenient choice in terms of 1) sample size; 2) heterogeneity of spending amount; 3) possibility to make comparisons with other countries; 4) potential relevance of results (Wollmann, 2004).

In order to enable theoretical replication and extend the research generalizability, two convenient samples from different countries were designed (Italy and the UK). This way, more local governments with similar characteristics (but different level of maturity in managing procurement) can be compared and, at the same time, differences related to the regulatory context can be taken into account.

For Italy, local municipalities accessible in our geographical area (Lombardy, Italy) were first targeted, with more than 35,000 citizens and yearly spending amount greater than 40 million euros. Twenty-three municipalities were first contacted and asked to participate in the research project, and four of them accepted. For the UK, we focused the attention on the Welsh region, considering the 22 principal areas ("county councils") existing after the reform of 1998. Furthermore, we considered relevant statistical factors such as population density, level of spending, and past procurement department rating. In the end we targeted and involved four councils.

\subsection{Case descriptives}

Table 2 summarizes the characteristics of the local authorities included in the 
analysis.

Some cases have been recorded with permission, while for others this was not possible due to confidentiality agreements. In these cases, two researchers were present and took notes during the meetings. However, we made sure that this did not affect the reliability of the information given, as the topics discussed did not show any social desirability bias or specific pattern across respondents. Interviews have been conducted (by two researchers) for at least one day per case, with interviewers' field notes used as the starting point for data analysis. More than 150 local government reports and institutional documents have been scouted in order to complement information (e.g. financial statements, internal reports, governmental reports and so on). Afterwards, within and cross-case analyses were conducted (Eisenhardt, 1989).

-TABLE 2-

\subsection{Interview protocol}

The interview protocol has been designed around the three components of our study: PP strategy, PP-PMS characteristics and PP status (Table 3).

-TABLE 3-

\section{Case analysis}

Once we had rationalized information collected through the interviews, we opted for a quantitative coding approach to facilitate cross-case comparisons. Table 4 gives an overview of cases evaluation.

-TABLE 4- 
First, we characterized the procurement organizational model for each case, distinguishing between (Dimitri et al., 2006): full centralization (all the relevant procurement decisions are in the hands of a central public unit that is dedicated to satisfying the needs of public offices); full decentralization (individual departments are delegated the power to decide how, what and when to procure); and a hybrid configuration (central and local procurement units share the decision-making authority in procurement).

Then, considering that the procurement department's role within the public institution may vary consistently according to its role (Murray, 2001; Telgen et al., 2007), we conceive the "status" as the extent to which procurement can act as a value-adding function. Operationally, we measure the procurement status as the average of several organizational characteristics reflecting such concepts as: reporting level, level of centralization, grouping criteria, span of control, purchasing recognition, and authority (Carr and Smeltzer, 1997; Gonzalez-Benito, 2004; Telgen et al., 2007). In particular, a numeric scale from 0 to 100 was adopted for each item, and scores were assigned considering relevant sub-components reported in the literature. For some items coding and scoring were straightforward (e.g., the level of centralization was calculated as the ratio between the spending centrally managed by the procurement department and the total spending), while for others we went through several steps (e.g., the span of control required to assess whether or not procurement was involved in operational activities, and/or sourcing activities, and/or strategic and planning activities).

Finally, an in-depth understanding of the PP-PMS is provided through some information on the explicit statement of strategic goals, number and nature of KPIs 
monitored, and their unit of analysis.

\section{Discussion}

The research investigates the structure of the PP-PMS for four municipalities in Italy and four councils in Wales, analysing KPIs used in six performance areas (i.e. cost, time, quality, compliance, innovation, sustainability) and at different levels of analysis (contract/supplier, procurement department, and other departments). Despite some general indications given by government regulation, we observed that each local authority develops its own way for measuring KPIs, so it is not possible to find a unique definition for each performance area, and the specific indicators are not systematically reported. However, considering the main evidence summarized in the previous sections, we can provide an answer to the three formulated research questions.

\subsection{Performance areas and measures for PP}

Even though every case includes at least two performance areas in their PP-PMS, as opposed to what theory prescribes (e.g. Rhys et al., 2006; Erridge and McIlroy, 2002), a precise correspondence between goals and performance measured is not always present. In some cases commercial goals are not defined, but cost indicators are measured anyway; in others socio-economic goals are promoted, but sustainability metrics are not defined (see Table 4).

Efficiency and cost KPIs are predominant, as more than $45 \%$ of measures explored relate to this dimension. This is not surprising, as this is the area traditionally monitored when dealing with procurement activities in the public sector, where there is the need to 
ensure resources are used in an efficient way (e.g. Chan and Karim, 2012). Cases demonstrate that there are different ways to evaluate the level of efficiency of PP: while local governments characterized by low-status procurement department limit their metrics to "Efficiency savings" or "Budget respect for a given category", other institutions enrich this dimension measuring process efficiency (e.g. "Average \% savings through the use of e-auctions") and savings coming from the use of specific procurement tools (e.g. “\% of corporate spend channelled through collaborative arrangements”).

Most importantly, evidence shows that, even in the least mature PP-PMS, cost is never the sole dimension included. Due to the regulative nature of PP, as well as the rigid policy and procedures set by local governments themselves, compliance is often included in PP-PMSs (19\% of KPIs collected in the cases): they generally referred to type of bidding process used for awarding contract (e.g. "number/value of procurement contracts awarded by means of non-competitive procedures/open/restricted procedure”), they can also include aspects linked to the use of governmental tools (e.g. "percentage of spending through the electronic marketplace”) or respect of internal objectives, such as human resources development (e.g. “hours of training for procurement professionals”). Quality and time dimension, despite being quite diffused for private procurement PMS (e.g. Day and Lichtenstein, 2006), are not so diffused in PP-PMS. Only some cases assess quality from the final user point of view (e.g. "Level of the customer satisfaction index"), and time spent by procurement resources in executing strategic and operational activities (e.g. “percentage of time dedicated to procurement planning”). This is somewhat reasonable, as these aspects are implicitly defined at contract level (for supplier quality requirements) and by procurement regulation (imposing mandatory process time limit for the different 
procedures).

Sustainability measures are not diffused either, and usually refer to mandatory aspects to be monitored and reported (e.g. "\% of spending with local suppliers"; "number of contracts awarded to SMEs"); only two cases monitor sustainability with additional KPIs, including product/service requirements (e.g. "\% of awarded contracts in which environment-related technical dimensions are considered either in the selection or the award criteria").

Finally, as we can see, innovation measures are not included in any PP-PMS explored, suggesting that, despite the emphasis given to this dimension (Edquist et al., 2015), current PP-PMS are lagging behind.

Finally, we can notice that the levels of analysis targeted by PP KPIs are usually homogeneously included (52\% of indicators refer to process level, $48 \%$ to contract level). Local governments usually set metrics for measuring procurement activities executed outside the procurement department in cases of hybrid and decentralized configurations, particularly for monitoring the cost and the compliance area.

Thus, we can conclude that cost metrics represent a relevant area of PP-PMS, but need to be placed aside other measures (especially compliance metrics, closely linked to internal procedures and external regulation). In particular, KPIs in the quality and innovation areas should be developed, as they seem quite neglected. Most importantly, the cases show the possibility of a misalignment between PP objectives and KPIs monitored, which should be carefully avoided, as the lack of coherence between strategy and measures is the main cause of poor performance (Boyne et al., 2005). 


\subsection{PP-PMS and PP status}

The cases can also help us in drawing some conclusions on the link between the "status" of the procurement department within the authority and the characteristics of the PP-PMS.

It is evident that the higher the status, the higher the number of KPIs defined and monitored, as two cases (CCY and CRH) confirm. CCB is an exception, using a large number of indicators despite its medium status, but this is explained by the recent reorganization of the department (evolving from a decentralized to a hybrid model), which was required to monitor performance. When the procurement department has only an operational and staff role (e.g. DVG and DPV), only a few and basic measures are defined ("savings" and "budget alignment"), and refer to external departments. This behaviour is somewhat damaging, hiding the real functioning of procurement activities, when they are executed by personnel without specific PP knowledge. When PP is affected by evident criticalities, structuring a sound PMS is essential to assure, at least, compliance and cost alignment: the case of CLN is a good example, as mainly cost and compliance KPIs are set, in order to constantly monitor activities and detect, as soon as possible, undesired behaviour of external users or cost increases for certain categories.

Furthermore, the cases show that, even when the number of KPIs monitored is significant, indicators do not equally split among different performance areas, as cost and compliance measures remain predominant; however, this is not necessarily a criticality, as where this happens (e.g. CCH, CRH, HCM), KPIs included are able to give managers an immediate understanding of the strengths and weaknesses of the process in any case.

Thus, we can conclude that, as the complexity and the level of detail of PP-PMS are 
a proxy of its status, in order to promote PP as a real value-adding function for public institutions, public managers should invest their time in designing an architecture and a sample of KPIs able to give a whole understanding of its functioning, even though not all the areas should be necessarily covered at all levels (e.g. McAdam et al., 2011).

\subsection{The role of regulation}

European governments are giving local councils more power to decide how to spend public money, so they can meet people's needs; at the same time, effective performance reporting by councils is essential for ensuring accountability to residents and taxpayers as to how public money is spent and the quality of services delivered. In the UK, the Openness of Local Government Bodies Regulations (2014), as part of the Local Audit and Accountability Act, impose on local councils the "Performance reporting framework”, made up of 66 measures and a governance and management checklist of 24 items which together build a comprehensive picture of council performance (including PP). In Italy, the 150/2009 regulation on "Local Government performance plan” requires

local governments to establish (and monitor) strategic and operational performance, giving also some suggestions for KPIs definition in each function (including PP).

We can therefore draw some insights about the influence of government regulation on the PP-PMS. It is interesting to notice that, of a total of 106 KPIs collected during the interviews, only $25 \%$ of them are published (in metrics and values) in official local government documents. In none of the cases, did the number of KPIs monitored correspond to the number of KPIs made available to the public. We can therefore conclude that government directives on PMSs represent a driving force for the PP-PMS 
design, as local bodies are "forced" to design performance metrics, but this is not enough to ensure the PP effectiveness. Indeed, PP-PMS must not be limited to mandatory metrics (e.g. "number of electronic tenders"; "average number of bids submitted in (open) competitive procedures", "number of procurement reports realized") as they certainly demonstrate that specific objectives are set for PP, but are not sufficient to diagnose problems and identify potential areas of improvement.

\section{Conclusions and future developments}

This work aims to provide more in-depth evidence of the characteristics and structure of PMS for procurement in the public sector, relying on the growing importance of PP as a government function (Thai, 2008), as well as the increasing attention on the linkage between strategy, goals and performance, also for the public sector (e.g. Rhys et al., 2009).

Assuming this perspective, our research questions aimed at studying what public institutions (i.e. local governments) are actually measuring, how much the structure of the PMS depends on the role that the procurement department is invested with within the authority, and the role of government regulation on PMS.

Empirical evidence shows that PP-PMSs are being developed, with some room for improvement. Most of the local governments included in the sample direct primary attention to cost and compliance indicators, with low attention to other traditional procurement areas (i.e. quality and time); with cost savings being the first evaluation parameter, it is not surprising that advanced contributions in areas such as innovation and sustainability are hardly measured, despite being part of the "new public management" 
principles (e.g. Meier et al., 2007).

Moreover, a connection between the procurement department status and the depth and completeness of its PMS is found: when PP is considered really strategic, more indicators are likely to be defined and monitored (McAdam et al, 2011; Jung and Kim, 2014). Similarly, we defined government directives as having a driving role towards a more structured approach to performance measurement, just being a starting point for the design of a complete set of indicators.

With these findings, the paper aims to contribute to research in two ways: on the one hand, it provides a synthetic framework (i.e. performance areas and level of analysis) for classifying procurement KPIs, in parallel with contributions by private PMS theories (e.g. Caniato et al., 2014); this framework is shown to be useful for analysing and comparing the structure and characteristics of procurement PMS for cases. On the other hand, empirical investigations gave us the possibility to analyse how procurement PMS are deployed operatively in local governments, investigating them from the broad process perspective, which is an exploration unique in its type and for the field of PP.

We claim our results to be interesting for practitioners as well, since our evidence supports the assumption that there is a mutual link between the evolution of the role of procurement in the public sector and approach in performance measurement. With the increase in the status and strategic contributions of PP, there is the need to build a comprehensive PMS, in order to assess its functioning in a new configuration (e.g. higher level of centralization, broader scope of its activities...); moreover, designing a complete PMS could be a starting point for supporting an increase in the status of PP, as the attention to KPIs measured is generally considered as a proxy to the importance of the 
function they refer to (Rhys et al., 2006). Public managers should also consider the fact that PP-PMS are driven (also) by regulation, which is subject to frequent change. In this regard, European directives are working towards a standardization of approaches and procedures (e.g. European Single Procurement Document), enabling diffusion and replication of best practices (as happened in the private sector; Arlbjorn and Freytag, 2012); however, as the process is still ongoing, managers should be able to design their system effectively by balancing guidelines defined at European and national level.

Of course, the research has its limitations: as the paper is descriptive in nature, the possibility of generalization is limited, especially because a particular type of public institutions (i.e. local governments) is explored. Future developments could be oriented towards further case studies addressing different public institutions, and comparing findings; otherwise, a more structured data collection (e.g. through survey) could be useful to test some of the specific links of the framework (e.g. goals and performance). Finally, it could also be interesting to expand the discussion on the linkage between country-level variables and PP-PMS structure (e.g. the role of culture, in connection with other studies, e.g. Moon, 2000). 


\section{References}

Afonso, Antonio, Ludger Schuknecht, and Vito Tanzi. 2005. Public sector efficiency: An international comparison. Public Choice 123 (3-4): 321-47.

Amann, M., J.K. Roehrich, M. Eßig, and C. Harland. 2014. Driving sustainable supply chain management in the public sector: The importance of public procurement in the European Union. Supply Chain Management: An International Journal 19 (3): 351-366.

Angiola, Nunzio, and Piervito Bianchi. 2013. Public managers' skills development for effective performance management: Empirical evidence from Italian local governments. Public Management Review (08/05; 2014/09): $1-26$.

Arlbjørn, J. Stentoft, and P. Vagn Freytag. 2012. Public Procurement vs private purchasing: Is there any foundation for comparing and learning across the sectors? International Journal of Public Sector Management 25 (3): 203-220.

Aschhoff, B., and W. Sofka. 2009. Innovation on demand-Can Public Procurement drive market success of innovations? Research Policy 38 (8): 1235-1247.

Axelsson, Björn, Jens Laage-Hellman, and Ulf Nilsson. 2002. Modern management accounting for modern purchasing. European Journal of Purchasing \& Supply Management 8 (1): 53-62.

Bartlett, Dean, and Pauline Dibben. 2002. Public sector innovation and entrepreneurship: Case studies from local government. Local Government Studies 28 (4): 107-21.

Beamon, Benita M. 1999. Measuring supply chain performance. International Journal of Operations \& Production Management 19 (3): 275-92.

Bennedsen, Morten, and Christian Schultz. 2011. Arm’s length delegation of public services. Journal of Public Economics 95 (7): 543-52.

Bergman, Mats A., and Sofia Lundberg. 2013. Tender evaluation and supplier selection methods in Public Procurement. Journal of Purchasing and Supply Management 19 (2): 73-83.

Boland, T., and A. Fowler. 2000. A systems perspective of performance management in public sector organisations. International Journal of Public Sector Management, 13 (5): 417-446.

Boyne, George A. 2006. Public service performance: Perspectives on measurement and management. Cambridge: Cambridge University Press.

Boyne, G. A., K. J. Meier, L. J. O’Toole, and R. M. Walker.2005. Where next? Research directions on performance in public organizations. Journal of Public Administration Research and Theory 15 (4): 633-639.

Caniato, Federico, Davide Luzzini, and Stefano Ronchi. 2014. Purchasing performance management systems: An empirical investigation. Production Planning \& Control 25 (7): 616-35.

Carr, Amelia S., and Larry R. Smeltzer. 1997. An empirically based operational definition of strategic purchasing. European Journal of Purchasing \& Supply Management 3 (4): 199-207.

Chan, Sok-Gee, and Mohd Abd Zaini Karim. 2012. Public spending efficiency and political and economic factors: Evidence from selected East Asian countries. Ekonomski Anali 57 (193): 7-23.

Chao, Chiangnan, Eberhard E. Scheuing, and William A. Ruch. 1993. Purchasing performance evaluation: An investigation of different perspectives. International Journal of Purchasing and Materials Management 29 (2): 32-9. 
Charbonneau, Étienne, and Gregg G. Van Ryzin. 2013. Benchmarks and citizen judgments of local government performance: Findings from a survey experiment. Public Management Review (05/23; 2014/09): 1-17.

Colton, R. R. 1962. Industrial Purchasing: Principles and Practices. CE Merrill.

Costantino, Nicola, Mariagrazia Dotoli, Marco Falagario, and Fabio Sciancalepore. 2012. Balancing the additional costs of purchasing and the vendor set dimension to reduce PP costs. Journal of Purchasing and Supply Management 18 (3): 189-98.

Coulson, Andrew. 2008. Value for money in PFI proposals: A commentary on the UK treasury guidelines for public sector comparators. Public Administration 86 (2): 483-98.

Croom, Simon, and Alistair Brandon-Jones. 2007. Impact of e-procurement: Experiences from implementation in the UK public sector. Journal of Purchasing and Supply Management 13 (4): 294-303.

Day, M., and S. Lichtenstein. (2006). Strategic supply management: The relationship between supply management practices, strategic orientation and their impact on organisational performance. Journal of Purchasing and Supply Management 12 (6): 313-321.

Dimitri, Nicola, Gustavo Piga, and Giancarlo Spagnolo. 2006. Handbook of procurement. Cambridge: Cambridge University Press.

Doherty, Neil F., Danny J. McConnell, and Fiona Ellis-Chadwick. 2013. Institutional responses to electronic procurement in the public sector. International Journal of Public Sector Management 26 (6): 495-515.

Easton, Liane, David J. Murphy, and John N. Pearson. 2002. Purchasing performance evaluation: With data envelopment analysis. European Journal of Purchasing \& Supply Management 8 (3): 123-34.

Edquist, Charles, Nicholas S. Vonortas, Jon Mikel Zabala-Iturriagagoitia, and Jakob Edler. 2015. Public Procurement for innovation. Edward Elgar Publishing.

Eisenhardt, Kathleen M. 1989. Building theories from case study research. Academy of Management Review 14 (4): 532-50.

Erridge, Andrew. 2005. UK Public Procurement policy and the delivery of public value. Challenges in PP: An International Perspective: 335-52.

Erridge, Andrew, and John McIlroy. 2002. Public Procurement and supply management strategies. Public Policy and Administration 17 (1): 52-71.

Gonzalez-Benito, J. (2007). A theory of purchasing's contribution to business performance. Journal of Operations Management, 25(4), 901-917.

Gunasekaran, Angappa, Chaitali Patel, and Ercan Tirtiroglu. 2001. Performance measures and metrics in a supply chain environment. International Journal of Operations \& Production Management 21 (1/2): 71-87.

Gushée, Edward Tisdale, and Lionel Frank Boffey. 1928. Scientific purchasing. McGraw-Hill Book Company.

Hayes, R. H., and S. C. Wheelwright. 1984. Restoring our competitive edge: Competing through manufacturing. Harvard Business Review, 63 (1), 99-109.

Higgins, Paul. 2005. Performance and user satisfaction indicators in British local government. Public Management Review 7 (3) (09/01; 2014/09): 445-66.

Jung, Chan Su, and Seok Eun Kim. 2014. Structure and perceived performance in public organizations. Public Management Review 16 (5) (07/04; 2014/09): 620-42. 
Karjalainen, Katri. 2011. Estimating the cost effects of purchasing centralization-Empirical evidence from framework agreements in the public sector. Journal of Purchasing and Supply Management 17 (2): 87-97.

Knudsen, Daniel. 1999. Procurement performance measurement system. Lund University Publications.

Kumar, Arun, Linet Ozdamar, and Chai Peng. 2005. Procurement performance measurement system in the health care industry. International Journal of Health Care Quality Assurance 18 (2): 152-66.

Kwon, Myungjung, and Hee soun Jang. 2011. Motivations behind using performance measurement: City-wide vs. selective users. Local Government Studies 37 (6): 601-20.

Lapsley, Irvine. 1999. Accounting and the new public management: Instruments of substantive efficiency or a rationalising modernity? Financial Accountability \& Management 15 (3-4): 201-7.

Lardenoije, Etienne JH, Erik M. van Raaij, and Arjan J. van Weele. 2005. Performance management models and purchasing: Relevance still lost. Paper presented at Researches in Purchasing and Supply Management. Proceedings, 14th IPSERA Conference, Archamps .

Luzzini, D., F. Caniato, and G. Spina. 2014. Designing vendor evaluation systems: An empirical analysis. Journal of Purchasing and Supply Management 20 (2): 113-129.

Mahoney, James. 2000. Path dependence in historical sociology. Theory and Society 29 (4): 507-48.

Matthews, Darin. 2005. Strategic procurement in the public sector: A mask for financial and administrative policy. Journal of Public Procurement 5 (3): 388.

McAdam, Rodney, and Timothy Walker. 2003. An inquiry into balanced scorecards within best value implementation in UK local government. Public Administration 81 (4): 873-92.

McAdam, R., Walker, T., \& Hazlett, S. A. (2011). An inquiry into the strategic-operational role of performance management in local government. International Journal of Public Sector Management, 24(4), 303-324.

McAfee, P., and J. McMillan. 1989. Government procurement and international trade. Journal of International Economics 26: 291-308

McLean, Iain, Dirk Haubrich, and Roxana Gutiérrez-Romero. 2007. The perils and pitfalls of performance measurement: The CPA regime for local authorities in England. Public Money and Management 27 (2): 111-8.

Meier, K. J., O'Toole, L. J., Boyne, G. A., \& Walker, R. M. (2007). Strategic management and the performance of public organizations: Testing venerable ideas against recent theories. Journal of Public Administration Research and Theory, 17(3), 357-377.

Meredith, Jack. 1998. Building operations management theory through case and field research. Journal of Operations Management 16 (4): 441-54.

Moon, M. J. (2000). Organizational commitment revisited in new public management: Motivation, organizational culture, sector, and managerial level. Public Performance \& Management Review, 177-194.

Murray, J. Gordon. 2001. Local government and private sector purchasing strategy: A comparative study. European Journal of Purchasing \& Supply Management 7 (2): 91-100.

Neely, Andy. 2005. The evolution of performance measurement research: Developments in the last decade and a research agenda for the next. International Journal of Operations \& Production Management 25 (12): 1264-77.

NIGP, 2012. Performance metrics. Principles and Practices of Public Procurement. 
Nisar, Tahir M. 2007. Value for money drivers in public private partnership schemes. International Journal of Public Sector Management 20 (2): 147-56.

OECD - Sigma, 2011. Performance measurement. Book - Brief 21.

OECD, 2013. Discussion paper on PP performance measures. OECD Meeting of Leading Practitioners on PP.

Poister, Theodore H., and Gregory Streib. 1999. Performance measurement in municipal government: Assessing the state of the practice. Public Administration Review: 325-35.

Preuss, Lutz. 2009. Addressing sustainable development through PP: The case of local government. Supply Chain Management: An International Journal 14 (3): 213-23.

Quirk, Barry. 2005. Localising efficiency-more than just saving money. Local Government Studies 31 (5): 615-25.

Radnor, Z., and M. McGuire. 2004. Performance management in the public sector: Fact or fiction? International Journal of Productivity and Performance Management, 53 (3), 245-260.

Raisbeck, Peter, Colin Duffield, and Ming Xu. 2010. Comparative performance of PPPs and traditional procurement in Australia. Construction Management and Economics 28 (4): 345-59.

Raymond, Jeanette. 2008. Benchmarking in PP. Benchmarking: An International Journal 15 (6): 782-93.

Rendon, R. G. (2008). Procurement process maturity: Key to performance measurement. Journal of Public Procurement 8 (2): 200.

Rhodes, Mary Lee, Lucia Biondi, Ricardo Gomes, Ana I. Melo, Frank Ohemeng, Gemma Perez-Lopez, Andrea Rossi, and Wayhu Sutiyono. 2012. Current state of public sector performance management in seven selected countries. International Journal of Productivity and Performance Management 61 (3): 235-71.

Rhys, Andrews, George A. Boyne, and Gareth Enticott. 2006. Performance failure in the public sector. Public Management Review 8 (2) (06/01; 2014/09): 273-96.

Saiz, Juan José Alfaro, Angel Ortiz Bas, and Raúl Rodríguez Rodríguez. 2007. Performance measurement system for enterprise networks. International Journal of Productivity and Performance Management 56 (4): 305-34.

Telgen, J., Harland, C., \& Knight, L. (2007). 2 Public procurement in perspective. Public procurement: international cases and commentary, 16.

Thai, Khi V. 2008. International handbook of Public Procurement. CRC Press.

Thai, Khi V., and Gustavo Piga. 2007. Advancing Public Procurement: Practices, innovation, and knowledge sharing. PrAcademics Press.

Trionfetti, Federico. 2000. Discriminatory Public Procurement and international trade. The World Economy 23 (1): 57 76.

Turley, Gerard, Geraldine Robbins, and Stephen McNena. 2015. A framework to measure the financial performance of local governments. Local Government Studies 41 (3): 401-20.

Verbeeten, Frank H. M. 2008. Performance management practices in public sector organizations: Impact on performance. Accounting, Auditing \& Accountability Journal 21 (3): 427-54.

Verdeaux, J. J. 2003. Public Procurement in the European Union and in the United States: A comparative study. Public Contract Law Journal 713-738. 
Voss, Chris, Nikos Tsikriktsis, and Mark Frohlich. 2002. Case research in operations management. International Journal of Operations \& Production Management 22 (2): 195-219.

Walker, Helen, and Stephen Brammer. 2012. The relationship between sustainable procurement and e-procurement in the public sector. International Journal of Production Economics 140 (1): 256-68.

Wall, Anthony, and Gary Martin. 2003. The disclosure of key performance indicators in the public sector. Public Management Review 5 (4) (12/01; 2014/09): 491-509.

Wollmann, Hellmut. 2004. Local government reforms in Great Britain, Sweden, Germany and France: Between multifunction and single-purpose organisations. Local Government Studies 30 (4): 639-65.

Yin, R. K. 1999. Enhancing the quality of case studies in health services research. Health Services Research 34 (5 Pt 2) (Dec): 1209-24.

Yuan, Jingfeng, Alex Yajun Zeng, Miroslaw J. Skibniewski, and Qiming Li. 2009. Selection of performance objectives and key performance indicators in public-private partnership projects to achieve value for money. Construction Management and Economics 27 (3): 253-70. 


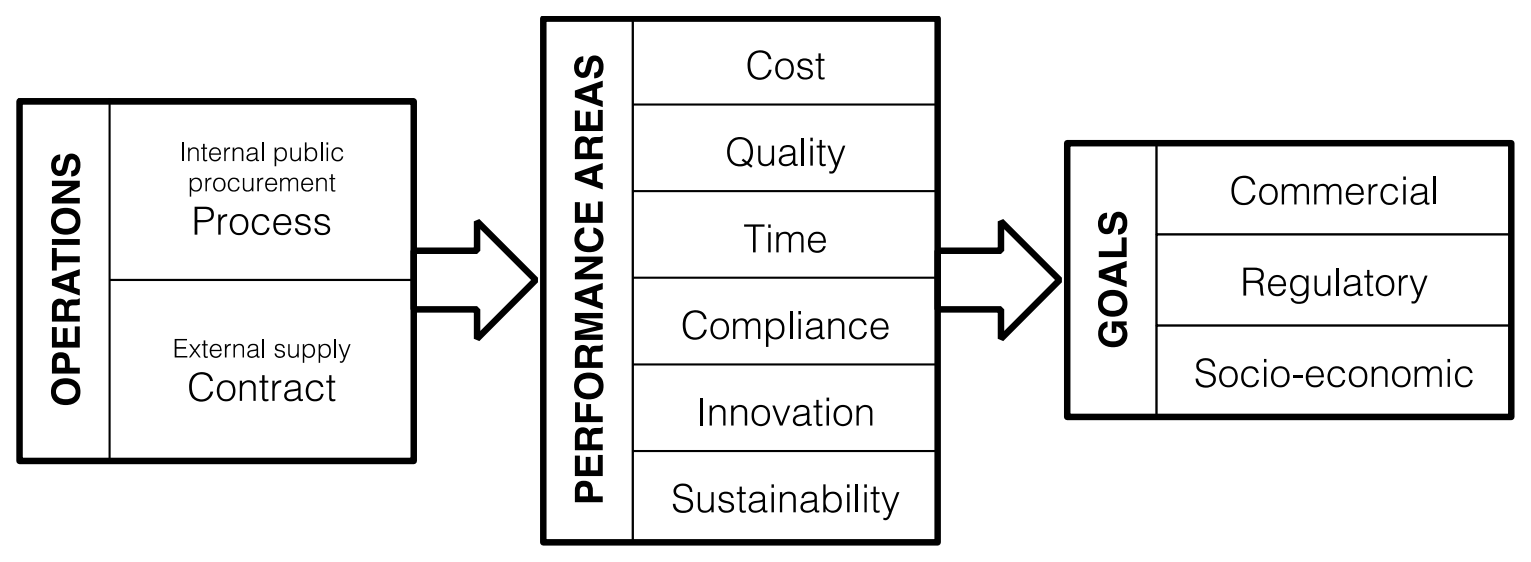

Figure 1: Research framework for PP-PMSs 


\begin{tabular}{|c|c|c|}
\hline & References & Example of measures \\
\hline Cost & $\begin{array}{c}\text { Afonso et al. (2005; 2010); } \\
\text { Quirk (2005) }\end{array}$ & $\begin{array}{l}\text { - } \text { Realized vs. identified savings ratio; } \\
\text { - Savings due to new contract/supplier } \\
\text { arrangements or procurement } \\
\text { initiatives; } \\
\text { - Awarded vs. estimated contract value } \\
\text { ratio. }\end{array}$ \\
\hline Quality & $\begin{array}{l}\text { Kumar et al. (2005); Thi et } \\
\text { al. (2012) }\end{array}$ & $\begin{array}{l}\text { - Supplier conformance to contract } \\
\text { specifications; } \\
\text { - Internal customer satisfaction. }\end{array}$ \\
\hline Time & $\begin{array}{l}\text { Hochschorner and } \\
\text { Finnveden (2006) }\end{array}$ & $\begin{array}{l}\text { - Procurement cycle time (from sourcing } \\
\text { to contract execution); } \\
\text { - Percentage of procurements activities } \\
\text { completed (placed) within standard } \\
\text { time guidelines }\end{array}$ \\
\hline Compliance & $\begin{array}{c}\text { Trionfetti (2000); Thi et al. } \\
\text { (2012) }\end{array}$ & $\begin{array}{l}\text { Percentage of contracts awarded } \\
\text { through non-competitive/open } \\
\text { procedures; } \\
\text { - Percentage of competitive contracts } \\
\text { awarded through of the VFM/MEAT } \\
\text { criterion. }\end{array}$ \\
\hline Innovation & $\begin{array}{l}\text { Knutsson and Thomasson } \\
\text { (2014); Edquist et al. } \\
\text { (2015) }\end{array}$ & $\begin{array}{l}\text { - Firms' increased investment on } \\
\text { innovation due to public procurement; } \\
\text { - Firms' increased capability of } \\
\text { innovation due to public procurement; } \\
\text { - Amount of patents due to public } \\
\text { procurement. }\end{array}$ \\
\hline Sustainability & $\begin{array}{l}\text { McCrudden (2004); Amann } \\
\text { et al. (2014) }\end{array}$ & $\begin{array}{l}\text { - } \\
\text { identified; } \\
\text { - } \\
\text { Number of firms involved in local } \\
\text { supplier development programs. }\end{array}$ \\
\hline
\end{tabular}

Table 1: Description of PP performance areas 


\begin{tabular}{|c|c|c|c|c|c|c|}
\hline & ID & Citizens & Spending & $\begin{array}{c}\text { Procurement } \\
\text { employees }\end{array}$ & Interviews & Job title \\
\hline \multirow{4}{*}{ 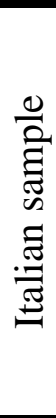 } & CLN & 60.000 & $45 \mathrm{mln} €$ & 5 FTE & 2 & $\begin{array}{l}\text { Head of Procurement, } \\
\text { Procurement Officer }\end{array}$ \\
\hline & HCB & 72.000 & $45 \mathrm{mln} €$ & 10 FTE & 2 & $\begin{array}{c}\text { Senior Procurement } \\
\text { Manager, Procurement } \\
\text { Officer }\end{array}$ \\
\hline & HCM & 75.000 & $60 \mathrm{mln} €$ & 15 FTE & 1 & Head of Procurement \\
\hline & DPV & 65.000 & $50 \mathrm{mln} €$ & 2 FTE & 2 & $\begin{array}{l}\text { Head of Procurement, } \\
\text { Procurement Officer }\end{array}$ \\
\hline \multirow{4}{*}{ 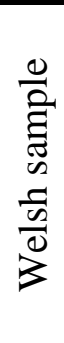 } & CCY & 180.000 & $£ 150 \mathrm{mln}$ & 18 FTE & 2 & $\begin{array}{l}\text { Head of Procurement, } \\
\text { Category manager }\end{array}$ \\
\hline & $\mathrm{CRH}$ & 250.000 & $£ 180 \mathrm{mln}$ & 24 FTE & 2 & $\begin{array}{c}\text { Head of Procurement, } \\
\text { Category manager }\end{array}$ \\
\hline & $\mathrm{HCF}$ & 350.000 & $£ 300 \mathrm{mln}$ & $18 \mathrm{FTE}$ & 1 & Head of Procurement \\
\hline & DVG & 120.000 & $£ 100 \mathrm{mln}$ & 2 FTE & 1 & $\begin{array}{l}\text { Procurement policy } \\
\text { officer }\end{array}$ \\
\hline
\end{tabular}

(data and name are approximate for confidentiality agreements)

Table 2: Descriptives of case studies 


\begin{tabular}{|c|c|c|c|c|}
\hline & Construct & Description & Main references & Interview question(s) \\
\hline 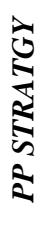 & Goals & $\begin{array}{l}\text { Degree of which } \\
\text { procurement objectives } \\
\text { are defined (considering } \\
\text { commercial, regulatory, } \\
\text { socio-economic } \\
\text { dimension) }\end{array}$ & $\begin{array}{l}\text { Erridge \& Mcllory } \\
\text { (2002); Erridge } \\
\text { (2005); Erridge } \\
\text { and Henningan } \\
\text { (2006) }\end{array}$ & $\begin{array}{l}\text { Do you explicitly define commercial, } \\
\text { regulatory and/or socio-economic goal } \\
\text { when defining the yearly procurement } \\
\text { strategic plan? }\end{array}$ \\
\hline$\sum_{\substack{n \\
1}}^{\infty}$ & Performance & $\begin{array}{l}\text { Areas and type of } \\
\text { performance measured } \\
\text { (cost, quality, time, } \\
\text { compliance, innovation, } \\
\text { sustainability) }\end{array}$ & $\begin{array}{l}\text { Rendon (2008), } \\
\text { Afonso and } \\
\text { Fernandez (2006), } \\
\text { Cadwell et al. } \\
\text { (2005) }\end{array}$ & $\begin{array}{l}\text { Do you have a procurement PMS? } \\
\text { Which types of performance are being } \\
\text { measured? Can you indicate specific } \\
\text { KPIs used for monitoring activities in } \\
\text { your Department? Which of these } \\
\text { performance are aligned with targets? }\end{array}$ \\
\hline \multirow{6}{*}{ 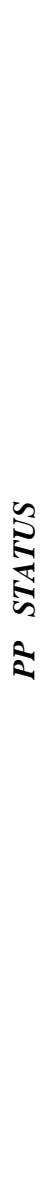 } & $\begin{array}{l}\text { Reporting } \\
\text { level }\end{array}$ & CPO reporting line & $\begin{array}{l}\text { Carr and Smeltzer } \\
\text { (1997); Johnson } \\
\text { and Leenders } \\
\text { (2006) }\end{array}$ & $\begin{array}{l}\text { Where the Procurement Department is } \\
\text { positioned in the organization chart? }\end{array}$ \\
\hline & $\begin{array}{c}\text { Level of } \\
\text { centralization }\end{array}$ & $\begin{array}{l}\text { Degree to which } \\
\text { procurement decision - } \\
\text { making and operational } \\
\text { activities are executed at } \\
\text { a central level }\end{array}$ & $\begin{array}{l}\text { Arnold (1999), } \\
\text { McCue et al. } \\
\text { (2000), Dimitri et } \\
\text { al. (2006), } \\
\text { Johnson and } \\
\text { Leenders (2006) }\end{array}$ & $\begin{array}{l}\text { Which is the percentage of spending } \\
\text { which is directly managed and/or in } \\
\text { charge to the Procurement Department? }\end{array}$ \\
\hline & $\begin{array}{l}\text { Grouping } \\
\text { criteria }\end{array}$ & $\begin{array}{l}\text { Criteria used for } \\
\text { grouping procurement } \\
\text { personnel }\end{array}$ & $\begin{array}{l}\text { Mintzberg (1980); } \\
\text { Lakemond et al. } \\
\text { (2001); Monczka } \\
\text { et al. (2009) }\end{array}$ & $\begin{array}{l}\text { How are resources grouped in the } \\
\text { department? Are employees organized } \\
\text { according to specific positions? (e.g. } \\
\text { category managers; buying/contracting; } \\
\text { p-cards administration; administrative } \\
\text { support; accounts payable...) }\end{array}$ \\
\hline & $\begin{array}{l}\text { Procurement } \\
\text { recognition }\end{array}$ & $\begin{array}{l}\text { Procurement's role and } \\
\text { capabilities as perceived } \\
\text { by others }\end{array}$ & $\begin{array}{l}\text { Carr and Smeltzer } \\
\text { (1997; 2000); } \\
\text { Cousins et al. } \\
(2006)\end{array}$ & $\begin{array}{l}\text { How procurement's role and resources } \\
\text { are considered by other Departments? }\end{array}$ \\
\hline & $\begin{array}{l}\text { Span of } \\
\text { control }\end{array}$ & $\begin{array}{l}\text { Type of activities } \\
\text { executed by the } \\
\text { Procurement } \\
\text { Department }\end{array}$ & $\begin{array}{l}\text { Erridge and } \\
\text { Mcllroy (2002); } \\
\text { Leenders et al. } \\
\text { (2006); Bakker et } \\
\text { al. (2008) }\end{array}$ & $\begin{array}{l}\text { Which type of activities are directly } \\
\text { executed by Procurement Department? }\end{array}$ \\
\hline & Authority & $\begin{array}{l}\text { Degree of decisional } \\
\text { authority on } \\
\text { procurement activities }\end{array}$ & $\begin{array}{l}\text { Birou and Fawcett } \\
\text { (1993) }\end{array}$ & $\begin{array}{c}\text { Which level of authority the } \\
\text { Procurement Department has on } \\
\text { procurement activities (e.g. operational } \\
\text { execution, decisional power, supportive } \\
\text { role...) }\end{array}$ \\
\hline
\end{tabular}

Table 3: Structure of the interview protocol 


\begin{tabular}{|c|c|c|c|c|c|c|c|c|}
\hline & \multicolumn{4}{|c|}{ Welsh sample } & \multicolumn{4}{|c|}{ Italian sample } \\
\hline & CCY & CRH & HCF & DVG & CLN & CCB & HCM & DPV \\
\hline $\begin{array}{c}\text { PP organizational } \\
\text { model }\end{array}$ & Centralized & Centralized & Hybrid & Decentralized & Centralized & Centralized & Hybrid & Decentralized \\
\hline PP status & 99 & 86 & 71 & 8 & 74 & 68 & 87 & 15 \\
\hline $\begin{array}{l}\text { Commercial goals } \\
\text { in the strategic plan }\end{array}$ & Yes & Yes & Yes & No & Yes & Yes & Yes & No \\
\hline $\begin{array}{l}\text { Regulatory goals in } \\
\text { the strategic plan }\end{array}$ & Yes & Yes & No & No & No & No & Yes & No \\
\hline $\begin{array}{c}\text { Socio-economic } \\
\text { goals in the strategic } \\
\text { plan }\end{array}$ & Yes & Yes & Yes & Yes & No & Yes & No & No \\
\hline $\begin{array}{l}\text { No. of KPIs } \\
\text { monitored }\end{array}$ & 18 & 23 & 8 & 4 & 13 & 25 & 12 & 3 \\
\hline $\begin{array}{c}\text { No. of KPIs } \\
\text { monitored and } \\
\text { published }\end{array}$ & 4 & 5 & 3 & 1 & 4 & 5 & 4 & 1 \\
\hline No. of COST KPIs & 7 & 13 & 2 & 3 & 7 & 9 & 7 & 1 \\
\hline $\begin{array}{c}\text { No. of QUALITY } \\
\text { KPIs } \\
\end{array}$ & 2 & 0 & 1 & 0 & 1 & 5 & 1 & 2 \\
\hline No. of TIME KPIs & 1 & 1 & 1 & 0 & 1 & 9 & 1 & 0 \\
\hline $\begin{array}{c}\text { No. of } \\
\text { COMPLIANCE } \\
\text { KPIs } \\
\end{array}$ & 4 & 6 & 2 & 1 & 4 & 0 & 3 & 0 \\
\hline $\begin{array}{c}\text { No. of } \\
\text { INNOVATION } \\
\text { KPIs } \\
\end{array}$ & 0 & 0 & 0 & 0 & 0 & 0 & 0 & 0 \\
\hline $\begin{array}{c}\text { No. of } \\
\text { SUSTAINABILITY } \\
\text { KPIs }\end{array}$ & 4 & 2 & 2 & 0 & 0 & 2 & 0 & 0 \\
\hline $\begin{array}{l}\text { No. of KPIs with } \\
\text { PROCESS as unit } \\
\text { of analysis }\end{array}$ & 8 & 14 & 3 & 1 & 3 & 19 & 5 & 2 \\
\hline $\begin{array}{l}\text { No. of KPIs with } \\
\text { CONTRACT as } \\
\text { unit of analysis }\end{array}$ & 10 & 9 & 5 & 3 & 10 & 6 & 7 & 1 \\
\hline No. of KPIs for $\mathbf{P P}$ & 18 & 23 & 6 & 1 & 13 & 20 & 8 & 2 \\
\hline $\begin{array}{c}\text { No. of KPIs for } \\
\text { other departments' } \\
\text { procurement }\end{array}$ & 0 & 0 & 2 & 3 & 0 & 5 & 2 & 1 \\
\hline
\end{tabular}

Table 4: Characteristics of cases included in the analysis 